\title{
THE LEGAL ENVIRONMENT OF SALMOND'S TIME
}

\author{
Jeremy Finn*
}

This paper examines through multiple lenses the world of the lawyer in early $20^{\text {th }}$ century New Zealand. It considers, and places in their social and political context, the major issues with which Parliament and the courts were dealing, notably issues to do with alienation of Māori land and attempts to prohibit the liquor trade, but also looking at law reform by private members' Bills. The reported decisions of the courts are analysed to consider the areas of frequent litigation, particularly land law (including Mãori land cases), administrative and public law cases thrown up by the prohibition question and the very large volume of torts cases. It then examines the position of the judiciary and the courts, paying particular attention to agitation by the profession for increased judicial salaries and to the debates about the role of the Privy Council following its judgment in Wallis's case. It concludes with a discussion of the organisation and membership of the legal profession, the state of legal education and the development of a body of locally-generated legal literature.

\section{INTRODUCTION}

What was the legal environment in New Zealand in 1906? What might John Salmond have found he needed to learn to appreciate the changes that had occurred in New Zealand legal culture since he had departed for Adelaide in 1897? We can approach these questions by examining a number of different and sometimes interlocking aspects of the legal scene in the first few years of the twentieth century in New Zealand. However we need first to consider the New Zealand to which he was returning.

This was a New Zealand which was enjoying renewed prosperity after the long depression of the 1890 s, with very substantial population growth through migration and natural increase, and not a little proud of its status as a laboratory for social and political reform. It is the era of Richard Seddon - "King Dick" and the beginning of "God's own country" - but even more it is the country working

* Professor of Law, University of Canterbury. I would like to acknowledge the assistance provided by my research assistants Hannah Stallard and Olivia Sinclair, and my appreciation to the Auckland, Canterbury, Otago and Wellington District Law Societies and the New Zealand Law Society for allowing me access to archival material. 
through the effects of great social and political experiments - female suffrage, inaugurating a system of industrial conciliation and arbitration, and being the first state to grant to its older citizens (at least those not of Asian descent) an old age pension. These developments all reflect a strong belief in many quarters of society in an activist state rather than individualism. ${ }^{1}$ Other social issues remained in contention - especially the question of control of the liquor trade and whether majorities of citizens should be able to enforce prohibition within their districts. These issues took up substantial space in both Parliamentary and judicial agendas.

Certain key features stand out as recurrent themes in public discourse at this time. The benefit of completing the North Island main trunk railway, as well as building provincial extensions, was a favourite topic. ${ }^{2}$ However nothing was seen as more important than making land available for further settlement. Seddon himself said in moving the second reading of the Land for Settlements Act Extension Bill 1905 that there was "land-hunger" from one end of the colony to the other. ${ }^{3}$ While some of that land came from Crown acquisition and subdivision of very large estates, primarily in the South Island's East Coast under the Land for Settlement Acts 1892 and $1894,{ }^{4}$ the main reservoirs of land were those in Māori hands. It may also be that the Lands for Settlements legislation encouraged tolerance of Government action and policies which interfered with property rights.

Thus the political or social imperative which saw James Carroll state that the Maori Land Settlement Bill 1905, designed to make easier the leasing of Māori land by Pakeha farmers, was an "honest endeavour to improve on the existing methods and procedure in regard to the alienation of Native lands". ${ }^{5}$ Just weeks earlier the Legislative Council had voted to require a return be prepared by the Surveyor-General assisted by a judge or judges of the Native Land Court giving approximately the total acreage of Native Land in the North Island which could be classed as unoccupied or unproductive, it being alleged there were millions of acres "absolutely unoccupied and wasted". 6

1 See Sir Robert Stout "New Zealand" (October 1899) Contemporary Review Wellington 541 (copy in Robert Stout Collection, Victoria University of Wellington Law Library).

2 See as one of many such references (10 July 1900) 111 NZPD 381-428 (HR).

3 (3 October 1905) 135 NZPD 394 (HR). See also the Governor's speech in 1904 to the effect that settlement of people upon the lands of the colony was of vital importance: (28 June 1904) 128 NZPD 4 (LC).

4 For example the acquisition and division of nearly 80,000 acres of land near present-day Seddon in the Starborough settlement (in 1899) and Flaxbourne settlement (in 1905). A picture of the counsel involved in assessing the price to be paid to the former owners of Flaxbourne appears in RB Cooke (ed) Portrait of a Profession (NZLS, Wellington, 1969) 57. They include CP Skerrett, HF Johnstone and JG Findlay.

5 (13 October 1905) 135 NZPD 702 (HR). See also (23 October 1905) 135 NZPD 959 (HR) and following.

6 (21 Sept 1905) 135 NZPD 53 (LC). 
In the following year the Governor's speech stated that: ${ }^{7}$

My advisers believe it will be to the interest of the Maori race, as well as to the great advantage of the whole colony, to provide that all Native lands should be beneficially occupied, either by the Maoris themselves or by Europeans. To accomplish this it is recognised that Native-land titles must be expeditiously dealt with and defined, the needs of the owners established and when they have surplus and unoccupied lands these will be acquired by the State for settlement. The creation of a Department for Native Affairs will expedite the carrying-out of such a policy.

We may explore the more specifically "legal" world of Salmond's time by looking at six facets of the legal environment in 1900-1906, the years immediately preceding Salmond's return to New Zealand. The first pair of these six facets are the principal legal issues raised in legislation over this period and the range of issues most commonly giving rise to litigation before the superior courts (Supreme Court and Court of Appeal as shown in the New Zealand Law Reports, and the Privy Council). This discussion will be followed by some statistical information about lawyers and courts in their societal context and by consideration of some matters concerning the organized legal profession at the time (as indicated through law society records, including legal education and legal writing of the period) before finishing with some consideration of the impact of Wallis's case and of calls for the abolition of appeals to the Privy Council.

\section{LEGISLATION}

\section{A Land-Especially Māori Land}

In 1900 Parliament passed two major legislative measures in the Maori Councils Act 1900 and the Maori Lands Administration Bill 1900 which between them gave Māori very many more powers to regulate their own affairs in relation to matters such as health and sanitation, and to make better use of what Māori land remained to them.

However, during the period under study, matters relating to Māori land predominate.

Some parts of the debates seem strange to the modern observer, such as suggestions from Māori members that the Government should limit the power of Māori to devise land by will, ${ }^{8}$ or that it was

7 (21 August 1906) 137 NZPD 3 (LC).

8 See (25 July 1900) 112 NZPD 155 (HR) (a reference apparently in part prompted by an unreported Supreme Court decision, which went on appeal as Sanders v The District Land Registrar, Napier (1902) 22 NZLR 275); and (2 July 1901) 116 NZPD 391 (HR). Both references were by Mr Tame Haereroa Parata, the MHR for Southern Māori; the latter drew response from the (part-Māori) Minister James Carroll, that opportunities for will-making on the part of Māori should be limited as much as possible. Parata's career is recorded in GH Scholefield (ed) The Dictionary of New Zealand Biography, Volume 2 (Department of Internal Affairs, Wellington, 1940) 373-4. 
an acceptable compromise that Māori land should be rated at half the level of land held by Pakeha while Māori did not have the right to vote in local body elections. ${ }^{9}$

It is important to recognize that much of this was done with strong Māori support, as where over 8,000 Māori had signed a petition urging the passage of the Native Land Administration Bill 1900. ${ }^{10}$ Māori did, however, want greater power for their Councils, in particular in regard to power to prohibit the sale of alcohol. ${ }^{11}$

It is also in this period that Māori exerted serious pressure on the Government to make available lands to those Māori who were currently without any land at all. ${ }^{12}$ In 1906 the Government did legislate to vest some land in the Māori of the South Island, acknowledging that previous promises to do so had long been unfulfilled. ${ }^{13}$

We must also remember that there were opposition members who believed the process of alienating Māori land was too complex and expensive. In 1900 one such member, Thomas Mason Wilford (Wellington Suburbs), ${ }^{14}$ suggested during the Address-in-reply debate that the Government should acquire the whole of the "Native" lands of the colony and make them Crown lands, with a fair sum in compensation to be paid to the Public Trustee to await the determination by the Courts of competing Māori claims to the fund thus created. ${ }^{15}$

We may particularly thank the parliamentarians of that era for attempting to ensure, for the first time, that there was some restriction on the exporting of Māori artefacts and for the beginning of a national museum collection. ${ }^{16}$ The Maori Antiquities Act 1901 forbade the export of Māori "relics"

9 See (9 July 1902) 120 NZPD 170; (21 November 1903) 127 NZPD 1009; and (7 July 1904) 128 NZPD 193$236(\mathrm{HR})$.

10 See (11 October 1900) 115 NZPD 90 (HR).

11 (29 July 1903) 124 NZPD 62 (HR).

12 See (28 September 1900) 114 NZPD 361-2; (20 September 1901) 118 NZPD 655; (21 September 1904$) 130$ NZPD 408 (HR).

13 South Island Landless Natives Act 1906, see (4 September 1906) 137 NZPD 316 (HR); and (9 October 1906) 138 NZPD 174-77 (LC).

14 Later as Sir Thomas Wilford, Minister of Justice 1910-1911. See Claudia Orange (ed) The Dictionary of New Zealand Biography, Volume 3 (Auckland University Press, Auckland, 1996) 568-69.

15 (27 June 1900) 111 NZPD 77-78 (HR).

16 On the desirability of a national collection, see (29 August 1900) 113 NZPD 312 (HR); and (6 August 1901) 117 NZPD 247 (HR). 
without a licence, ${ }^{17}$ but it was found that penal provisions were needed to ensure compliance with the legislation, which provisions were introduced in $1904 .^{18}$

\section{B Prohibition and Social Reform}

Not surprisingly given the prohibition issue, licensing issues also took up substantial amounts of Parliamentary time. There were substantial licensing Bills in 1900, 1902 and 1904. Prohibition interests were, however, clearly less strong in Parliament itself than in many electorates - when in 1900 Parliament was required to conduct a liquor poll under section 13 of the Alcoholic Liquors Sale Control Act Amendment Act 1895 to determine whether liquor should continue to be sold within the precincts of the Parliament Buildings, a majority of 34 for continuance was recorded. ${ }^{19}$

Whatever were people's stance on the liquor trade, there is no doubt that there was a reasonably broad consensus on the desirability of state action against social vices. Thus we see the passing of the Opium Prohibition Act 1901 which was seen as necessary because although it was widespread among the Chinese population it was thought that it would "contaminate" the European populations, particularly young people. ${ }^{20}$ The following year the legislation was made more stringent, apparently at the instigation of a back-bench MP. ${ }^{21}$

The same moral reformist element can be seen in the Juvenile Smoking Suppression Act 1903 which was one of a number of successful Bills promoted by a private member. The Act made it illegal to supply tobacco to "youths", or for them to consume tobacco in a public place unless the individual smoker had been recommended to consume tobacco by a medical practitioner. ${ }^{22} \mathrm{~A}$ slightly more pragmatic view was taken in the gaming and lotteries legislation which merely attempted to protect the public rather than banning what was seen as an ineradicable social habit. ${ }^{23}$

\section{Changes to Courts and Procedures}

There were no major reforms of the court structure at this time. There was an expansion of the Supreme Court bench by one in 1900, a move said to be justified by the need for a judge to chair the

17 The first suggestion for legislation appears to have been in 1901: see (9 July 1901) 116 NZPD 195 (HR). For debates on the 1901 bill see (4 October 1901) 119 NZPD 216 (HR).

18 See Māori Antiquities Act Amendment Act 1904, and (28 September 1904) 130 NZPD 548 (HR).

19 (25 July 1900) 112 NZPD 145 (HR).

20 Hon W C Walker (17 October 1901) 119 NZPD 447 (HR).

21 Opium Prohibition Act Amendment Act 1902, see (5 August 1902) 121 NZPD 156 (HR).

22 See sections 2, 3 and 4 respectively. For the debates see (18 September 1901) 118 NZPD 588 (LC); (11 September 1901) 118 NZPD 400 (LC); and (30 July 1903) 124 NZPD 127 (HR).

23 See for example William Pember Reeves on the Gaming and Lotteries Bill 1901 (18 September 1901) 118 NZPD 590 (LC). An amending Act was passed in 1905. 
Court of Arbitration as well as the general pressure of business. There was widespread support for the change but it is notable that many parliamentarians took the view that it was as important to increase the level of judicial salaries as to alleviate the workload. ${ }^{24}$

That view was widely shared. The inadequacy of judicial salaries was on several occasions the subject of comment by Law Societies - and indeed the topic of a public delegation to the Acting Premier by the Wellington Law Society in 1902 seeking an increase in salary to $£ 2000$ for puisne judges and $£ 2500$ for the Chief Justice. The newspapers of the time endorsed the call for an increase. ${ }^{25}$ Although some increase was granted in 1905 (puisne judges rose to $£ 1800$ and Chief Justice to £2000) it was less than had been sought and the Law Societies almost immediately noted its insufficiency. ${ }^{26}$

Calls for changes to the system to make it work better were sometimes heeded. There were two significant changes made by the Indictable Offences Summary Jurisdiction Act 1900. The first was a purely pragmatic move to allow significantly more indictable offences to be tried summarily in the Magistrates' Court. ${ }^{27}$ The second change was to bring in a general rule that an accused facing summary trial for an offence (other than assault) for which he or she might be sentenced to more than three months imprisonment should have a right to elect jury trial. This important point was not part of the original Government Bill, but was proposed at Committee stage by an Opposition Member of the House of Representatives, Charles Lewis who said he drew it from the English Summary Jurisdiction Act 1879. It is a fair reflection of legislation of this period that a very significant change to the rights of the accused - one still important today - was made with little

24 See (17 July 1900) 113 NZPD 47. The House rejected the first motion to put the bill into committee: see (21 August 1900) 113 NZPD 146 (HR). However three days later it was put through committee and passed: see (24 August 1900) 113 NZPD 247. The voting pattern raises the possibility that some politicians in favour of an additional judge nevertheless voted to delay the bill as a way of emphasising the need for movement on salaries. See also n 125 below.

25 For District Law Society comment see Minutes of ADLS Council 28 October 1901, ADLS Archives; and Minutes of ODLS Council 4 October 1901 and ODLS AGM 7 February 1902, ODLS Archives. The ODLS Council was however cautious enough to resolve to delay writing until the President was satisfied that the Premier had indeed made a speech acknowledging the need for higher judicial salaries. The deputation was recorded by the local newspapers, see (22 September 1902) Evening Post Wellington 5; and it received editorial endorsement, see Editorial "The Judges' Salaries" (23 September 1902) Evening Post Wellington 4. The same material was reported, with similar editorial endorsement in (23 and 25 September 1902) New Zealand Times Wellington, both recorded in clippings in Minute Book of NZLS Council, NZLS Archives.

26 Supreme Court Judges Salaries Act 1904, s 3; Minutes of WDLS Council 8 April 1905, WDLS Archives.

27 The Act raised the limit for indictable offences of theft or false pretences from property of a value of $£ 5$ to that worth $£ 20$; as well as allowing Magistrates to hear cases of attempted suicide, indecent assault, and injuring animals. 
discussion and no apparent consideration of the practical implications, implications with which the criminal justice system continues to struggle. ${ }^{28}$

Other significant changes to the criminal law also came without Government initiatives. The most important was the Criminal Code Amendment Act 1900 which for the first time made incest a criminal offence. The amendment was very largely due to agitation by the the New Zealand Society for the Protection of Women, ${ }^{29}$ which clearly convinced a majority of parliamentarians that action was needed. The second was the addition of criminal libel in 1901 by the Criminal Code Amendment Act 1901. That Act was prompted by the Court of Appeal's decision in $R v$ Mabin, ${ }^{30}$ where it was held that the Criminal Code Act 1893 had, inadvertently, removed that offence from New Zealand law. The amending Act passed through both Houses of Parliament and received the royal assent in less than two weeks.

A similar pattern of reform initiated by individuals or reform groups appears in other areas. The classic example is the well-known Testator's Family Maintenance Act 1900. The legislation has been ably discussed elsewhere, ${ }^{31}$ but it is significant both in the fact that a major reform was the result of a Private Member's Bill rather than Government action, and as showing the willingness of the New Zealand Parliament to let its views of the merits of the case for reform (and the voting power of the many female proponents of change) override any respect for abstract rights of property and freedom of testation.

Another Bill which caused much debate among lawyers was the Property Law Bill 1904. This had a chequered parliamentary history before passage in 1905. It is a mark of the nature of much New Zealand law at this point that the Bill was advanced as being essentially a consolidating statute but with the adoption of certain English provisions which were thought desirable. ${ }^{32}$

There were matters of public law which occupied the attention of parliamentarians on occasion and would probably have been of general interest to most lawyers. First we should note that it is in this period that members of the legislature were first paid a salary. ${ }^{33}$ Second perhaps is the fact that moves to provide for referenda failed in both 1901 and 1903, but as late as 1905 the Government

28 The debate is reported in (21 September 1900) 114 NZPD 119 (HR) and following. The new procedure was considered in $R v$ Reid (1902) 20 NZLR 604 (SC). The current legislative provision is Summary Proceedings Act 1957, s 66.

29 See (12 September 1900) 113 NZPD 472 (LC). One dissentient, Sir GS Whitmore, rejected the Bill as "a libel on the people of New Zealand": see 475-6.

$30 R v$ Mabin (1901) 20 NZLR 451 (CA).

31 See R Atherton "New Zealand's Testator's Family Maintenance Act of 1900 - The Stouts, the Women's Movement and Political Compromise" (1990) 7 Otago LR 202.

32 (29 Sept 1905) 135 NZPD 313 (LC).

33 Payment of Members Act 1901. 
had inserted the need for provision for them into the Governor's speech. ${ }^{34}$ It seems probable that referenda were seen primarily as a matter of resolving any deadlock between the two chambers of Parliament without the ministry having to run the risk that an election might cost them control of the House of Representatives. ${ }^{35}$ Certainly the Legislative Council was not willing to see referenda introduced. The 1903 Bill was lost by the remarkable margin of 26 to two at its second reading. ${ }^{36}$ This would thus appear to be one of the very few significant Government Bills rejected after the taming of the Legislative Council in the 1890s.

Lastly, it is important to remind ourselves that although female franchise had been allowed some years earlier, there were still uphill struggles for feminists and their sympathisers, as evidenced in the debate on the Removal of Women's Disabilities Bill 1900. This was a Private Member's Bill to allow women to sit in Parliament which passed its second reading in the House of Representatives by 9 votes in 1900, ${ }^{37}$ but was killed in committee. The nature of the debate and of contemporary views can be seen by contrasting the views of its mover, George Warren Russell of Christchurch: ${ }^{38}$

$[\mathrm{I}] \mathrm{t}$ is an utterly illogical position that the franchise should be extended to the women of our country but that they should be debarred, on the ground of sex alone, from taking any further part in politics than that of recording their votes. It appears to me to be illogical and anomalous that a naturalised Chinaman should be able to take his place in the Legislature of this colony, whilst an educated, refined, wealthy, and able woman should be debarred from taking a place in the Legislature because of sex.

One of its leading opponents, the reactionary William Hughes Fisher of Otaki, called the Bill a "travesty" and "too suggestive of feeding-bottles and perambulators". 39

\section{CASE LAW}

We can approach the case law of this period in a number of ways. ${ }^{40}$ If we take the cases decided from 1900 to 1906 in volumes 18-25 of the New Zealand Law Reports as an inexact but reasonably accurate proxy of litigation raising significant issues of law in the Supreme Court and Court of

34 (27 June 1905) 132 NZPD 5 (LC).

35 Understanding of referenda and their use may have been enhanced by the votes on liquor licensing which took place at every parliamentary election from 1893. I am indebted to Patrick McCabe for drawing this to my attention.

36 (13 November 1903) 127 NZPD 571 (LC).

37 (27 June 1900) 111 NZPD 149 (HR) and following.

38 See Scholefield Dictionary of New Zealand Biography, Volume 2, above n 8, 432-34.

39 Respectively (27 June 1900) 111 NZPD 149 (HR) and (27 June 1900) 111 NZPD 150 (HR).

40 The following study is based on cases in the New Zealand Law Reports as the official series of reports. Although a number of other cases appear in the Gazette Law Reports, it appears the trends of the NZLR are largely maintained. 
Appeal in those years, we have a collection of just over 1000 reported decisions. ${ }^{41}$ Of those rather more than an eighth (137 of 1018) deal with issues of civil practice and procedure. That leaves around 880 substantive decisions. There are three areas which stand out and require extended treatment: land law, including the alienation of Māori land; liquor licensing in its broad sense; and the law of torts. However before looking at those, we may quickly survey the other major fields of litigation.

\section{A "Residual Areas" of Law}

1 Criminal matters

We may begin with the criminal work of the courts. There was a quite substantial tally of 57 cases on criminal law - including police or summary offences and criminal evidence or criminal procedure. Of course the Law Reports only included decisions on points of law. In this regard it is interesting that although the Criminal Code Act 1893 had allowed a form of appeal on the facts of a case in that an accused could, with the leave of the trial judge, seek to have the Court of Appeal order a new trial on the basis of the verdict being against the weight of evidence - section 416 of the Criminal Code Act 1893 - the first case in which there was substantial discussion of that provision and the test to be applied was in 1901 in $R v$ Styche. ${ }^{42}$

There were several cases of importance on issues of general principles of criminal liability of which perhaps the case of $R v$ Ewart deserves mention as it set the standard for liability for serious regulatory offences which was applied until $1970 .{ }^{43}$

Two other features of the criminal cases may be mentioned. Firstly, there were several cases on the parameters of the offence of incest, made criminal only in $1900 .{ }^{44}$ Secondly, there were a surprising number of cases - six - involving lotteries and gaming. These include a series of cases

41 The total appears to be 1018. This figure over-represents the individual number of actions involved, as appeals from reported decisions are included in the count, and there are a substantial number of cases where interlocutory proceedings (sometimes several such) are reported separately from the substantive hearings. The reported decisions in these volumes include a few cases from outside the period, and of course some legally important litigation may not have been reported. The Gazette Law Reports did report some cases not appearing in the NZLR, but few involved significant legal issues. Even allowing for these limitations, we may draw some broad conclusions from the data.

$42 R v$ Styche (1902) 20 NZLR 744 (CA). The test to be applied by the trial judge in considering whether to grant leave was not set down clearly until 1905 in $R v$ Broderson (1905) 25 NZLR 861 (SC). See also $R v$ Allandale \& Dennett (1905) 25 NZLR 507 (CA).

$43 R v$ Ewart (1905) 25 NZLR 709 (CA). Others were $R v$ Mathieson (1906) 25 NZLR 879 (SC) (intoxication) and $R v$ Austin (1905) 24 NZLR 983 (CA) (attempts).

$44 R$ v Minnis (1903) 22 NZLR 856 (CA); $R$ v Stanley (1903) 23 NZLR 378 (CA) and $R$ v Geddeson (1906) 25 NZLR 323 (SC). 
interpreting legislation aimed at Chinese gamblers playing Chinese games of chance. ${ }^{45}$ The courts read such legislation restrictively, and thus usually held that prosecutors had not established the elements of the offence under the legislation.

Perhaps the most unusual criminal case to the modern eye was the unsuccessful appeal against a conviction for criminal libel, only recently added to the Crimes Act, ${ }^{46}$ after the successful prosecution of a Christchurch lawyer, Wilfred Badger. ${ }^{47}$

\section{Civil matters}

(a) Families and estates

There are substantial clusters of litigation in two areas - family law and the law of wills and succession. The latter was the larger in number of cases litigated with over 60 cases involving deceased estates - either on construction of the will (by far the largest group at 48) or disputes as to estates left on trust (7). We may note that there were a further seven cases where applications had been made under the new Testator's Family Maintenance Act 1900.

There was also a reasonably substantial body of matrimonial litigation - almost all in the Supreme Court. ${ }^{48}$ The vast bulk of this litigation - 18 of 25 cases - was concerned with divorce law, which had been significantly liberalised in the Divorce Act 1898 and then again in the Divorce and Matrimonial Causes Act 1904. The widened grounds for divorce are reflected in the cases while eight related to petitions relying on adultery, ${ }^{49}$ there were three founded on desertion, ${ }^{50}$ two

45 Joe Quick v Cox (1902) 21 NZLR 584 (SC); Joe Tong and Others v Cox (1902) 21 NZLR 591 (SC); Joe Ping v McGrath (1905) 25 NZLR 892 (SC); Lee Sun v Conolly (1905) 24 NZLR 553 (SC). The other gaming cases were Harrison and Another v McGrath (1903) 22 NZLR 676 (SC); R v Eager (1903) 23 NZLR 552 (SC).

46 Criminal Code Act Amendment Act 1901.

$47 \quad R v$ Badger (1904) 23 NZLR 89 (CA). Badger, known to some legal historians for his compilations of New Zealand statutes published in 1884 and 1887 , had alleged that another lawyer had forged a document showing authority to commence a legal action.

48 In this period the only two "family" law cases in the Court of Appeal were Hall v Hall (1902) 21 NZLR 251 (CA) and Bewes v Bewes (1903) 23 NZLR 665 (CA).

49 Owen v Owen (1905) 25 NZLR 64; Duff v Duff (1904) 23 NZLR 674 and Hall v Hall (1902) 21 NZLR 251.

50 Beaumont v Beaumont (1904) 25 NZLR 143; Douglas v Douglas (1904) 23 NZLR 584; Fisher v Fisher (1904) 23 NZLR 386. 
on judicial separation, and one each on habitual neglect and habitual drunkenness. ${ }^{51}$ We may also include in the "family law" area three cases on maintenance of children under other statutes. ${ }^{52}$

(b) Contracts, companies, mining and tax

Contract cases loomed large with over 60 cases in the reports, ranging over virtually every contractual principle. Special mention may be made of the important case of Riddiford $v$ Warren, which considered extensively the rules of common law and equity as to rescission of a contract for misrepresentation. ${ }^{53}$ As might be expected for such a major industry there were quite a number -17 - of mining cases. There were also 31 cases on company law - about a third of which appear to have involved issues of winding-up of the company or its liquidation. In a sign of things to come, there were also 34 cases on revenue matters - gift duty, stamp duty and, latterly, income tax.

\section{B Land}

Land law was a staple area of litigation throughout the period. There were over 60 decisions on land law issues other than those involving Māori. It is significant that a only about one fifth of these (13/63) appear to have involved land where the title was under the Land Transfer Act (Torrens) system, a reminder of the relatively slow progress in bringing land held privately under the Act.

However these figures tell only a part of the story. There were around 36 cases involving issues relating to Māori land. One of the most striking features of the law reports for this period is the frequency of litigation over Māori land from 1901-1902. The New Zealand Law Reports include five cases decided in 1901 concerning Māori land - one being Solicitor-General v The Bishop of Wellington and Others, ${ }^{54}$ later to be known as Wallis's case - and no fewer than ten in 1902 of which five were in the Court of Appeal. That tally includes multiple hearings in Mere Roihi and Others $v$ The Assets Company Limited, ${ }^{55}$ and two actions which were ostensibly about points of

51 Respectively Pearce v Pearce (1905) 25 NZLR 683; Hoy v Hoy (1906) 25 NZLR 857; Mackie v Mackie (1903) 22 NZLR 567 and Dempsey v Dempsey (1905) 24 NZLR 829.

52 Arrowsmith v Manning (1901) 19 NZLR 180; Rhodes v Cooper (1904) 23 NZLR 562; and Smith v Smith (1906) 25 NZLR 33.

53 Riddiford $v$ Warren (1901) 20 NZLR 572 (CA).

54 Solicitor-General $v$ The Bishop of Wellington and Others (1901) 19 NZLR 665 (CA). The others were In re Tahanui Block No 2 (1901) 20 NZLR 76; Solicitor-General v The Bishop of Wellington and Others (1901) 19 NZLR 665 (CA); In Re Hawke's Leases (1901) 19 NZLR 34 and In re Tahora (1901) 20 NZLR 643 (CA). I have not counted here Moore v The Public Trustee (1901) 20 NZLR 288 (CA) which is in form an action about the validity of a lease registered under the Land Transfer Act of land given by a limited Crown grant, although the lessors were Māori and the grant followed from Crown acquisition of Māori land.

55 Mere Roihi and Others $v$ The Assets Company (Limited) (1902) 21 NZLR 449, 673 and 691; the others being Teira Ranginui and Others $v$ The Assets Company (Limited) et al (1902) 22 NZLR 1 (CA); Panapa Waihopi and Others $v$ The Assets Company (Limited) (1902) 22 NZLR 37; Niniwa Heremaia and Others $v$ The Minister of Lands (1902) 22 NZLR 54; Timu Kerehi and Another v Duff (1902) 22 NZLR 206; The 
procedure where Māori claiming interests in land which was already the subject of litigation sought to bring actions of their own relating to the land. One of these related to the land in question in Wallis's case, ${ }^{56}$ the other was in issue in Mere Roihi's case. Several of the Court of Appeal decisions later went on appeal to the Privy Council. This is not the occasion for a detailed analysis of the decisions but it is striking to note that the effect of them was in almost all cases to confirm the alienation of Māori land.

\section{Liquor Licensing}

One of the most striking features of the New Zealand Law Reports for the first few years of the twentieth century is the frequency with which matters to do with the liquor licensing laws were before the courts. Those reports contain 44 liquor licensing or liquor industry cases over the seven year period. The bulk of these dealt with elements of offences in the liquor licensing legislation. There were no fewer than eight cases between 1901 and 1905 dealing with the statutory exception that allowed sale of alcohol to bona fide travellers outside the normal licensing hours. ${ }^{57}$ Eleven other cases concerned the offences under the legislation including three cases on the sale of liquor to, or allowing consumption of liquor by, a drunken person. ${ }^{58}$

However, the most hotly contested issues related to the validity of licensing polls or the effect of the voters' decisions. Two cases concerned the process for challenging the results of a poll, ${ }^{59}$ while five others were challenges to decisions later made by licensing committees where it was alleged the committee had acted inconsistently with the poll result or otherwise not followed the law. The liquor interests were slightly more successful in the courts than their opponents, with two of these five decisions going in favour of the temperance crusaders. ${ }^{60}$

King v Airini Tonore (1902) 22 NZLR 220; Sanders $v$ The District Land Registrar, Napier (1902) 22 NZLR 275 (CA) and Izard v Tamahau Mahupuku (1902) 22 NZLR 418.

56 Hohepa Wi Neera $v$ The Bishop of Wellington and Others (1902) 21 NZLR 655.

57 Stanton v James (1901) 19 NZLR 392; Hammond v Hobson (1903) 23 NZLR 395; Clark v Sheehan (1903) 22 NZLR 767; Payne v Johnston (1903) 22 NZLR 176; Perry v Rasmussen (1903) 22 NZLR 581; Cooper v Andrews (1903) 22 NZLR 1010; McGrath v Patton (1904) 24 NZLR 527. The exception was greatly reduced by Parliament in 1904, see Brooking v Crawford (1905) 24 NZLR 738.

58 See McVeigh v Eccles (1899) 18 NZLR 44; Dwyer v Herman (1900) 19 NZLR 209; and Houldsworth v Fairhall (1905) 25 NZLR 1.

59 Bastings v Stratford (1900) 18 NZLR 513; and Bond v Johnson (1903) 22 NZLR 697.

60 The prohibition interest succeeded in Corby v McArthur (1903) 23 NZLR 419 where the Court held the poll result meant the Licensing Committee had no jurisdiction to grant or renew licenses within the district and in Silk v The Caversham Licensing Committee (1903) 22 NZLR 873 where Stout CJ held the statutory criteria for reducing the number of licences had been correctly applied. However in In re $W$ \& G Turnbull \& Co's Application (1903) 23 NZLR 489, it was held (Stout CJ dissenting) that the carrying of the proposal that the number of licenses existing in the district shall continue did not prevent the Licensing committee granting further new licenses. In Outred v Keddell and Others (1906) 25 NZLR 853 Cooper J held the 


\section{Tort}

The last area of litigation requiring extended discussion is the broad field of tort law. Firstly, this was one of the largest areas of litigation by volume - 56 cases in this period. Secondly, we may be sure that John Salmond, as the writer of the leading text on tort law, would have been likely to have paid close attention to the development of New Zealand law in this area.

By far the largest group of the reported cases relate to liability for negligence in its various forms. Some of these cases involved relatively novel and interesting points such as the question of liability for enabling a person to commit suicide, ${ }^{61}$ where it was held that the duty to prevent suicide arose when the defendant was aware that the person in their care had become insane (the Court also had to consider whether insanity was a defence to a tort action for assault). A feature which stands out is the high number - six - of actions against local bodies for negligence. In most cases the local body was able to find immunity because it had not exceeded its statutory powers, ${ }^{62}$ though liability attached where the body had in good faith exceeded its authority, ${ }^{63}$ or where a negligent contractor had been employed. ${ }^{64}$

By contrast there are but two cases of an action against the national government, both relating very broadly - to the government railways. The first of these, Linklater v Minister of Railways had to determine the duty of care toward passengers of the railway operator, and Williams $\mathrm{J}$ relied heavily on American cases. ${ }^{65}$

There were also four cases on employers' liability for negligence, ${ }^{66}$ and three relating to alleged negligence in failing to control livestock in public areas. ${ }^{67}$

licensing committee could not reduce the number of "accommodation" licenses; and in Ex parte Gaukrodger, In re O'Driscoll's Application (1902) 20 NZLR 660, it was held even though a statute restricted the removal of licences from one location to another, this did not prevent a licensee abandoning a licence and obtaining a fresh licence for a new building.

61 Respectively McFarland v Stewart (1900) 19 NZLR 22 (CA) and Donaghy v Brennan (1900) 19 NZLR 289.

62 The Otago Harbour Board v John Lysaght (Limited) and Others (1901) 20 NZLR 541 (CA); The Mayor, Councillors, and Burgesses of The Borough of Palmerston North v Fitt and Another (1902) 20 NZLR 396; Shearer v The Mayor, Councillors, and Citizens of the City of Dunedin (1904) 24 NZLR 192.

63 Blunden $v$ The Inhabitants of the Oxford Road District (1902) 20 NZLR 593 (CA).

64 Carnahan $v$ The Borough of North Invercargill (1902) 21 NZLR 175. The last cases was Tulloch $v$ The Wellington Harbour Board (1904) 24 NZLR 20 dealing with apportionment of damages.

65 Linklater $v$ Ministry of Railways (1900) 18 NZLR 536. The other case was Hankins $v$ The King (1905) 25 NZLR 787 (CA), regarding failure to ensure that a street was safe where the railway crossed it.

66 McIntosh v Stewart (1900) 19 NZLR 152; The Wellington and Manawatu Railway Company (Limited) v McLeod (1900) 19 NZLR 257; Doyle v The New Zealand Candle Company (Limited) (1901) 20 NZLR 686, and Tarabochia v Howden \& Co (1906) 25 NZLR 970. There were also four cases on liability under the 
Negligence was not the only area of tort law explored. There were twelve cases on aspects of defamation: seven of slander ${ }^{68}$ and five of libel. ${ }^{69}$ To round out the range of tort cases, there were five on nuisance - including the well-known Warner's Limited $v$ The Lyttelton Times Company (Limited), where it was held by the Court of Appeal that the respondents were liable in nuisance for the vibrations caused by their printing presses, a verdict reversed on appeal, ${ }^{70}$ and four actions for trespass including one for trespass on Māori land. ${ }^{71}$ Other torts included action for release of fire, ${ }^{72}$ malicious bringing of a civil action, ${ }^{73}$ deceit, ${ }^{74}$ and false imprisonment. ${ }^{75}$

One final point should be made about the case law element in New Zealand law at this time. The years on which this account focuses were part of a period where American authorities were regularly cited and adopted by New Zealand judges - particularly by Stout CJ and Williams J. We must not forget that there were important exceptions to the generally Anglo-centric world view of New Zealand lawyers. ${ }^{76}$

\section{E Privy Council Appeals}

A slightly different picture is obtained when we look at the matters which were sufficiently important to the litigants to be appealed to the Privy Council in the period 1900-1906. There are in the various law reports - the single volume of cases reported as New Zealand Privy Council Cases,

Employers Liability Act 1882. It should be noted that from 1900 employees could, under the Workers' Compensation for Accidents Act 1900, bring claims for injuries suffered in the course of employment in the Court of Arbitration. Cases in that court were not then reported in the NZLR.

67 Northern Steamship Co (Ltd) v Fleming (1902) 21 NZLR 551; Patterson v Fleming (1904) 24 NZLR 676 (CA); Paul v Rowe (1904) 24 NZLR 641.

68 Thomas v Perham and Perham (1901) 21 NZLR 199; Crowley v Brown (1902) 22 NZLR 334 (CA); Jellicoe v Haselden (1903) 22 NZLR 343 and Freeman v Pope (1905) 25 NZLR 529.

69 Pilcher v Knowles (1900) 19 NZLR 368; and Coughtrey v The Evening Star Company (Limited) (1902) 21 NZLR 116.

70 Warner's Limited $v$ The Lyttleton Times Company (Limited) (1906) 25 NZLR 746 (CA); reversed [1907] AC $476(\mathrm{PC})$

71 Harper v Harper (1900) 20 NZLR 317; Freer v Holmes (1902) 22 NZLR 197; Strang v Russell (1904) 24 NZLR 916 and Mere Hikatu v Russell (1905) 25 NZLR 315

72 Kelly v Hayes (1902) 22 NZLR 429.

73 Cross v The Commercial Agency Ltd (1900) 18 NZLR 153.

74 Foley's Creek Extended Company v Cutten and Faithful (1903) 23 NZLR 759.

75 Bouvy v Count de Coutre (1902) 20 NZLR 312.

76 I have examined this phenomenon in depth elsewhere, and emphasised the importance of the use by New Zealand lawyers of American legal publications, see Jeremy Finn "New Zealand Lawyers and 'Overseas' Precedent 1874-1973 - Lessons from the Otago District Law Society Library" (2007) 11 Otago LR 469. 
the New Zealand Law Reports and the English reports - 21 Privy Council appeals decided in the period $1900-1906 .{ }^{77}$ There were certainly some other cases never reported, but the number is unknown. ${ }^{78}$

Of the 21 reported cases no less than four are to do with issues relating to the alienation of Māori land or its consequences. These include the most notorious case of the period, Wallis $v$ Solicitor-General, ${ }^{79}$ as well as the leading cases of Nireaha Tamaki v Baker, ${ }^{80}$ and Assets Co Ltd v Mere Roihi. ${ }^{81}$ Three other cases also involved issues relating to land or property law: a question of title to land as between the Crown and a claimant relying on purchase from the New Zealand Company; ${ }^{82}$ compensation for land taken by a local body under the Public Works Act; ${ }^{83}$ and compensation for pollution of a stream. ${ }^{84}$

In shades of the future of New Zealand litigation there were also two cases dealing with taxation issues: one as to death duties and an income tax case turning on whether the respondent, a British company, was deriving income in New Zealand. ${ }^{85}$ The only other areas of law considered on more than one occasion were to do with the validity of polls under the liquor licensing statute ${ }^{86}$ and, broadly stated, issues of contract. $^{87}$

The remainder of the Privy Council decisions ranged over issues as diverse as civil procedure, matrimonial law, wills, the disciplining of a lawyer for professional misconduct, local body law, agency, forfeiture of improperly labeled goods, and the rights of a debenture holder in railways of

77 Curiously only 12 appear in HF von Haast (ed) New Zealand Privy Council Cases 1840-1932 (Wellington, Butterworths, 1938).

78 See the reference to NZ Loan \& Mercantile $v$ Reid (unreported, c1902) in an Appendix to W Downie Stewart Life and Times of Sir Francis Bell (Wellington, Butterworths, 1937) 311.

79 Wallis v Solicitor-General (1903) NZPCC 23.

80 Nireaha Tamaki v Baker [1901] AC 561 (PC).

81 Assets Co Ltd v Mere Roihi (1905) NZPCC 275. The fourth case was Te Teira Te Paea v Te Roera Tareha (1901) NZPCC 399.

82 Riddiford $v$ The King (1905) NZPCC 109.

83 Wellington City Corporation v Johnston (1902) NZPCC 645.

84 Heslop v Minister of Mines [1904] AC 781

85 Respectively Jackson v Commissioner of Stamps (1903) AC 350 and Commissioner of Taxes v Eastern Extension Australia and China Telegraph Co Ltd [1902] AC 526.

86 Smith v McArthur (1904) NZPCC 323 and Bastings v Callaghan [1905] AC 351.

87 Clouston \& Co Ltd v Corry (1905) NZPCC 336 and Lodder v Slowey (1904) NZPCC 60. 
which the government had taken possession. ${ }^{88}$ One other feature of these cases is worthy of comment - the rate of success by an appellant was close to 50 per cent, not dissimilar to that of the early 1990s, though much higher than the rate in the later 1990s. ${ }^{89}$

\section{LAWYERS, JUDGES AND THE LEGAL STRUCTURE}

\section{A Some Statistics and Other Data}

We are able to make some reasonably informed estimates of the numbers of legal practitioners at the beginning of the twentieth century. The Secretary of the Wellington District Law Society kept records of the number of practicing certificates issued nationally in every year between 1896 and 1905, and we have census data for 1901 and 1906. The numbers of solicitors as shown by the practicing certificates indicates a period of fluctuating numbers from 1896-1902, followed by sharp growth in the following three years.

Table 1: Solicitor's practicing certificates 1896-1905

\begin{tabular}{|c|c|c|c|c|c|c|c|c|c|}
\hline $\mathbf{1 8 9 6}$ & $\mathbf{1 8 9 7}$ & $\mathbf{1 8 9 8}$ & $\mathbf{1 8 9 9}$ & $\mathbf{1 9 0 0}$ & $\mathbf{1 9 0 1}$ & $\mathbf{1 9 0 2}$ & $\mathbf{1 9 0 3}$ & $\mathbf{1 9 0 4}$ & $\mathbf{1 9 0 5}$ \\
\hline 524 & 574 & 556 & 577 & 596 & 603 & 574 & 614 & 661 & 710 \\
\hline
\end{tabular}

Clearly there are some unusual features of these numbers. The sharp rise from 1896 to 1897 is difficult to explain with certainty as indeed are the fluctuations over the following few years. There must have been a class of admitted solicitors who drifted between the legal profession and other forms of economic activity depending on economic conditions generally. ${ }^{90}$ It is more difficult to estimate the number of lawyers practicing as barristers sole, but the number was probably only

88 Respectively, Mitchell v New Zealand Loan and Mercantile Agency Co, Ltd (1903) NZPCC 495; Wasteneys v Wasteneys (1900) NZPCC 184; Allan v Morrison [1900] AC 604; Jellicoe v Wellington District Law Society (1900) NZPCC 310; Mayor etc of Wellington v Mayor etc of Lower Hutt [1904] AC 773; Fleming v Bank of New Zealand [1900] AC 577; Commissioner of Trade \& Customs v R Bell \& Co Ltd [1902] AC 563 and Coates v The Queen [1900] AC 217.

89 See the data in Margaret Wilson Reshaping New Zealand's Appeal Structure: Discussion Paper (Office of the Attorney-General, Wellington, 2000) para 9.

90 It was noted in 1906 that a land broker was advertising the fact he was a solicitor as well. Minutes WDLS Council meeting 25 June 1906, WDLS archives. 
around 30-35. ${ }^{91}$ We should also note that the 1906 census revealed a doubling in the number of female practitioners - to two. ${ }^{92}$ There was however only one Māori practitioner in these years. ${ }^{93}$

It must also be remembered that at this time of the population of New Zealand was rising sharply - from 772,719 in 1901 to 888,578 in 1906 - which is an increase of around 12 per cent in 5 years. While we do not have practicing certificate numbers for 1906, it would seem that the number of solicitors was roughly keeping pace with the population. It is however difficult to see where these new practitioners came from. It is clear that by far the largest growth in numbers was in Wellington - half of all admissions in 1904-1905 were in the capital. ${ }^{94}$ It is not clear whether these were mainly locals or whether a significant number of these new practitioners were immigrants from England or Australia. ${ }^{95}$

It is interesting and informative to look further at some of the data for the early twentieth century and compare it with data from a century later as the contrasts may give us some insights into the strikingly different patterns of practice in the earlier period. Consider the following table:

Table 2: Solicitor's practicing certificates by regions 1904-1905 and 2005

\begin{tabular}{|l|c|c|}
\hline & $\mathbf{1 9 0 4 - 0 5}$ & $\mathbf{2 0 0 5}$ \\
\hline Auckland & 122 & 4213 \\
\hline + Waikato/BOP & & 844 \\
\hline Canterbury & 101 & 996 \\
\hline
\end{tabular}

91 The census figure for barristers and solicitors in 1901 was 636, while 603 solicitors' practicing certificates were issued. The difference of 33 cannot be taken as precisely establishing the number of barristers as some practitioners may have been absent from the colony at census date). The 1906 census showed 785 barristers and solicitors, which may indicate a somewhat greater number lawyers practising as barristers sole in that year.

92 It has been said that this was because Stella May Henderson, a Christchurch practitioner, had followed Ethel Benjamin into the practice of law, see Carol Brown Ethel Benjamin: New Zealand's First Woman Lawyer (BA(Hons) Dissertation, Otago University, 1985). However Henderson left New Zealand by 1903 for Melbourne, see Scholefield Dictionary of New Zealand Biography, Volume 2, above n 8, 209. It is possible she briefly returned to New Zealand and was counted in the 1906 census. No other candidate is known.

93 Thomas Rangiwahia Ellison was in practice from 1893 till his death in 1904. Apirana Ngata was admitted to the profession in 1897 but did not practice: Cooke, above $n$ 4, 394-395.

94 "Wellington District Law Society Annual General Meeting" (29 April 1905) Evening Post Wellington 5, copy in WDLS archives.

95 Unfortunately Wellington did not, as for example Otago did, indicate whether new practitioners had qualified in New Zealand. The proportion in Dunedin of immigrants was quite low - three of about 30 admissions (the data is a little imprecise) in 1903-1905. Reports of ODLS AGMs 1904, 1905 and 1906, ODLS Archives. 


\begin{tabular}{|l|c|c|}
\hline Gisborne & 17 & 46 \\
\hline Hawkes Bay & 33 & 197 \\
\hline Marlborough & 8 & 137 \\
\hline Nelson & 14 & 341 \\
\hline Otago & 30 & 127 \\
\hline Southland & 44 & 139 \\
\hline Taranaki & 161 & 2412 \\
\hline Wellington & & 130 \\
\hline +Manawatu & 15 & 66 \\
\hline +Wanganui & 661 & 9,721 \\
\hline Westland & & 24 \\
\hline Total & & \\
\hline
\end{tabular}

We must note the very different position in relation to barristers sole. As we have seen the number in of such barristers in 1901 was probably around 33, or perhaps 1 in 20 lawyers. In 2004 there were 1,119 - or about 1 in 10 lawyers.

Even more striking is the fact that in 2004, there were 849 new admissions to the profession - a total greater than the total of practising lawyers a century earlier.

We may note in passing that the number of women in the legal profession had risen to about 38 per cent in 2004 - with 59 per cent of newly-admitted practitioners in that year being women.

The leading position of Wellington as a center for the legal profession is very clear in the 1904 figures - even though it is a less dominant position than that now enjoyed by Auckland. It must be remembered that the Otago, Auckland, Canterbury and Wellington figures will include both city practitioners and those in the country areas in the region. The proportions of these are hard to determine, though it was said in the Wellington District Law Society Annual Report for 1901 that of 91 members of the Society, 28 came from country areas. ${ }^{96}$ However 51 solicitors were not members of the Society, and it is plausible that a higher proportion of these were in country areas. Although the lawyers represented by the smaller societies, and the rural and provincial practitioners within the major societies, clearly make up a substantial proportion of the practitioners of the period, it seems probable that the bulk of lawyers were still in the four main urban centres.

96 See WDLS Annual Report, as reported in (23 April 1901) New Zealand Times Wellington. 
Another way of looking at the data is that in the years immediately before John Salmond's return to New Zealand, there was very roughly one legal practitioner for every 1200 to 1300 persons in the general population.

Given that in 2004 the New Zealand population neared 4 million, we can see that there was one lawyer for every 370 persons - at least three times as many.

Those contrasts cannot be pursued further here, but they do give a clear warning that we must be very careful not to assume that the current experience of the position of lawyers in New Zealand society reflects that of a century ago.

Curiously this difference in proportions of lawyers to population is not nearly so marked when we look at the salaried judiciary. In the early 1900s, there were six, and later seven judges of the Supreme Court; three District Court judges (one of whom was also a Stipendiary Magistrate); and 27 other Stipendiary Magistrates. There were also seven judges of the Native Land Court. The total salaried judiciary for New Zealand was around 44. This is roughly one salaried judicial officer to 20,000 persons in the population.

It appears that in 2004 there were 181 judges of one kind or other in New Zealand - or around one judge for every 22,000 of population, ${ }^{97}$ a remarkably similar proportion. Given that the 2004 figures include Supreme Court judges and the 1900s figures exclude the Privy Council, the numerical disparity is even less. However such a comparison does, of course, take no account of the much larger judicial role of Justices of the Peace in the early $20^{\text {th }}$ century. Nor does it reflect the interesting shift of the proportion of salaried judicial officers at higher levels of the court structure.

\section{B Being a Lawyer}

We may gain some useful insights into the day-to-day routines of law offices at this time from the contents of a petition to Parliament by the Law Students' Society of Wellington seeking (successfully) to ensure that law firms were not brought within the proposed Shops and Offices Bill 1906. The petition stated that the ordinary working hours were six and a half hours per day, with a standard half-day on Saturdays. Further, law firms observed more holidays than other professions or businesses - around 30 a year. Law clerks were paid for all these holidays, and usually given time to study. It was acknowledged that on occasion some overtime was worked from pressure of business but this was not oppressive. The Society also expressed its opposition, in terms which very much

97 The tally is 5 Justices of the Supreme Court, 7 of the Court of Appeal, 29 permanent and 4 acting Justices of the High Court; 4 permanent and 2 acting Associate Justices of the High Court, 112 District Court Judges, 4 Employment Court judges, 7 Environment Court Judges and 8 Judges of the Māori Land Court. 
echo the students' petition, though adding (at the risk of inconsistency) that although law clerks rarely worked overtime, the costs of it under the Bill would be prohibitive. ${ }^{98}$

As the students and the New Zealand Law Society had noted, the profession observed a very substantial number of legal holidays. The historian of the Auckland District Law Society has suggested the long list of holidays observed in 1900 showed the "small town flavour" of legal practice in Auckland at this time, but it seems to me that this is erroneous. Wellington may well have observed even more holidays. During 1904-1905 there were 4 half-holidays for football matches or funerals and 10 weekday full holidays (plus four which fell on weekends) not counting the Christmas holidays. ${ }^{99}$

There were, of course, also different expectations as to the kinds of cases lawyers would take. Many more minor criminal matters were dealt with through private prosecutions - so much so that Auckland lawyers could successfully seek to have the local District Court Judge set aside one day a week where private prosecutions would get priority second only to prisoners in custody, rather than be delayed while all police cases were heard. ${ }^{100}$

\section{Legal Education and Entry to the Profession}

The limited facilities for legal education at this time have been well described by the historians of the various law societies and in other works. However we should remind ourselves of certain key features. At all four University Colleges there was at least some attempt to provide lectures in law for the students who were aiming to pass the LLB degree as a part of the qualification for admission and as a barrister and solicitor.

There were at this time two different paths to admission as a barrister. The normal route required not only the passing of the barristers' examination in law but also either a university degree or the passing of the barristers' general knowledge examination. For many solicitors this was an

98 Memorandum of petition by Wellington Law Students, and (but probably August 1901), in WDLS minute book for 1901, WDLS archives. That petition was clearly drawn on for the text of the NZLS submission to Parliament in 1903, as to which see Minutes NZLS Council 11 July 1903, NZLS archives.

99 See DF Dugdale Lawful Occasions (ADLS, Auckland, 1979) 6. The Auckland list for 1900 included 29 January Anniversary Day; 17 March St Patrick's Day; Easter, Good Friday, Easter Sunday and Easter Tuesday, both inclusive; 23 April St George's Day; 24 May the Queen's Birthday; 9 November the Prince of Wales's Birthday; 30 November St Andrew's Day; and Christmas Eve to $4^{\text {th }}$ January, both inclusive. The Wellington data is in WDLS Memoranda book 1905-1906, WDLS archives. A committee of the WDLS did seek in 1906 to have deleted from the regular legal holidays "Saint Patrick's Day, Saint George's Day, Saint Andrew's Day, the day of the lawyers versus insurance cricket and football matches, Licensing Election Day and Arbour Day". The Council however did decide later that year that a half-holiday was to be observed for the Southland v Wellington football match! See Minutes of WDLS Council 25 June and 21 August 1906, WDLS archives.

100 Minutes of ADLS Council 13 November 1905 and 22 January 1906, ADLS Archives. 
unattractive route. While the law exam was probably not very demanding, the general knowledge examinations may have been a considerable stumbling block to some applicants, as it required knowledge of Latin and, according to critics, of other subjects "many of which are absolutely useless to a legal practitioner". ${ }^{101}$

However, as Michael Cullen has shown, a change made to the Law Practitioners Act 1898 which allowed admission as a barrister to solicitors of five years standing who had passed the solicitors' examinations in law - the so-called "back-door" to becoming a barrister - resulted in a significant change in the qualifications sought by would-be lawyers. There was a significant decline in applicants for admission who had a university degree and a substantial rise in those who sought admission on the basis of passing the solicitors' examinations. ${ }^{102}$

The combination of the fused profession and the "back-door" entry provision was never an entirely happy one. Two consequences of it should be mentioned here. The first is that the process of qualifying for admission as a barrister through the back-door was slow with the five year wait and may have been costly. There was an attempt in 1903 by some solicitors to seek a further amendment to the legislation which would allow solicitors who had served four years under articles and passed the barristers' examination to be enrolled as barristers on that basis without passing the general knowledge examination - and without waiting five years from the date of admission as a solicitor. Two distinct groups had pushed for this change. One was described in New Zealand Law Society documents as "a section of the barristers and solicitors in the Otago district" but it was one which did not have the support of the provincial law society. ${ }^{103}$ The other group was an Auckland faction which had the support of Frederick Ehrenfried Baume, a Member of Parliament and the then President of the Auckland District Law Society, ${ }^{104}$ who unsuccessfully introduced a Bill in 1903. ${ }^{105}$

The other consequence of the fused profession was its impact on proposals for reciprocity of admission between England and New Zealand. After the passage of the Colonial Solicitors Act 1900 (Imp), the British authorities made it clear from 1901 that New Zealand solicitors could be brought

101 Petition of Otago solicitors to Parliament 1903, copy in Minutes of NZLS Council meeting 11 July 1903 , NZLS Archives.

102 MJ Cullen Lawfully Ocupied (ODLS, Dunedin, 1979) 121-2. It is not clear how much this may have been influenced by the problems of the provision of law lectures at Otago. Nor, unfortunately, can we make any real comparison with other centres.

103 Minutes of NZLS Council meeting 11 July 1903, NZLS archives.

104 (6 August 1903) 124 NZPD 304 (HR); see also Minutes of NZLS Council Meeting 11 July 1903, NZLS archives.

105 The Debates record a partial second reading debate - (6 August 1903) 124 NZPD 304 and following (HR) but nothing further. The WDLS Annual Report 1904 (25 April 1904) WDLS archives, makes it clear the Bill had failed. 
under the Act, and thus allowed simple admission in England, only if the New Zealand law was altered to allow English solicitors to be admitted in New Zealand on the basis of the English qualification. However the Inns of Court would not countenance reciprocal admission procedures which might admit to the English bar a New Zealand solicitor, whether or not also a barrister in New Zealand. It would seem the New Zealand profession rapidly sought to persuade the Government to bring forward a Bill to make the necessary changes to the New Zealand legislation, which occurred in 1903, with the necessary Orders-in-Council to bring New Zealand solicitors under the English Act being made in 1904. ${ }^{106}$

A last point of relevance to entry to the profession is that because all law students were at this time also in employment (usually in law offices), the local District Law Societies were necessarily involved in educational issues. The Wellington District Law Society may well have been the least supportive of law students. Its attitudes toward local law students had been heavily, if possibly unfairly, criticised in 1900 at a meeting of the College Council, which considered a request by the law students that the College spend $£ 131$ on the purchase of law reports and law journals to be placed in the College Library. The College Council decided to provide three-quarters of that amount if the Law Society gave the remainder. One member of the College Council, a Mr Hogg, was reported as having described the Wellington Law Society as a "cormorant" on the basis that it was one section of the legal profession robbing the other. Other epithets used could not, we are told, be reported without liability for defamation. ${ }^{107} \mathrm{He}$ referred to the Society's charge of two guineas per head for students to use the Library, and compared this with the plight of country practitioners who, he said, were continually complaining that although they had to pay an annual subscription to the Society Library, they got no benefit from it. Indeed he alleged the Society was accumulating large capital funds at the expense of the students. The Acting Chairman of the College Council was reported as saying these statements were exaggerated because the Law Society often made donations to various libraries and distributed old editions of books. ${ }^{108}$ It would appear no-one was aware that the Wellington District Law Society charge was twice that levied in Dunedin, or later, in Auckland. The Society apparently sought to ride out, rather than actually challenge, this criticism, but it did readily agree to provide details of its finances as sought by an MP in the light of the

106 See Copy "Despatch" Colonial Office to Governor, 22 August 1902, forwarded by Under-Secretary for Justice to NZLS (12 November 1902), in NZLS Minute Book 1902, NZLS archives. See Memorandum of WDLS deputation to Premier 5 April 1902, WDLS Minute Book 1902, WDLS archives; and (21 July 1903) 123 NZPD 599-600 (LC).

107 "Local and General" (21 June 1900) Evening Post Wellington 5, clipping with Minutes of WDLS Special Council Meeting 21 June 1900.

108 See (21 June 1900) New Zealand Times Wellington; and "Local and General", ibid, copies included with Minutes of WDLS special Council Meeting 21 June 1900. 
newspaper reports. ${ }^{109}$ In the following year the Council agreed to a law student request to allow access to the library between July and the middle of November (when the exams were sat) for the reduced fee of one guinea - with, however, the significant limitation that this did not allow access when the Court of Appeal was sitting. ${ }^{110}$

\section{Legal Writing}

There were few textbooks on Zealand law published at this time. An analysis of the acquisitions of the Otago District Library records indicates that eight New Zealand texts (including new editions) were acquired between 1900-1906, along with three works covering both Australia and New Zealand. ${ }^{111}$

There was no New Zealand legal journal at this time, but a number of writers on legal topics published their views either through the newspapers or by publishing small pamphlets or tracts. The range of such pamphlets was enormous, from railway reform to new prison systems by way of industrial conciliation and arbitration, temperance and currency reform. ${ }^{112}$

We may also get some impression of the areas of interest to lawyers in New Zealand by looking across the Tasman at the range of material appearing in the Commonwealth Law Review. That journal was published in Sydney from 1903 to 1909, initially quarterly but later monthly and we may reasonably expect that John Salmond would have been well aware of its contents.

Much of the content of this journal in its first years focuses on aspects of the Constitution and the law of the new Commonwealth of Australia, as well as a steady flow of material referring to the law or practice of the United States and Canada. ${ }^{113}$ Later issues contained a more eclectic range, but

109 Minutes WDLS Council meeting, 12 June 1900, WDLS archives. Given that the Financial Report of the Society was printed together with the Annual Report and that document appears to have been given to the press, it would have been difficult to withhold this information.

110 Minutes of WDLS Library Committee, 1 July 1901, and WDLS Council, 13 January 1902, WDLS Archives. The issue was revisited the following year where it was agreed that the fee was to stay at two guineas per year, but that students could pay for separate six month instalments.

111 ODLS Library Catalogue 1934, ODLS Archives.

112 A large number of these are collected in the Robert Stout collection, JC Beaglehole Room, Victoria University of Wellington Law Library.

113 For example, in the first volume, DG Ferguson "Interstate Service of Process" (1903) 1 Commonwealth LR 18-22; John Quick "Commonwealth Legislation and Judicial Interpretation" (1903) 1 Commonwealth LR 62-68; A Inglis Clark "The Supreme Court of the United States during the first Half Century of its Existence" (1903) 1 Commonwealth LR 3-12; 69-78. There was also a piece by G Flos Greig (the first woman lawyer in Australia) "The Law as a Profession for Women" (1909) 4 Commonwealth LR 145-154. 
with some emphasis on industrial law and the interplay of an arbitration system and the common law. ${ }^{114}$

The journal did not, however, confine itself to Australian authors. In 1904 it published an article by Sir Robert Stout criticising the Privy Council as being slow to decide cases and unfamiliar with local conditions. ${ }^{115}$ Stout advocated the abolition of colonial appeals to the Privy Council, with each colony deciding its own appellate structure, although he put forward in the article a plea for a single Australasian final appellate court. Other New Zealand contributions in the period to 1906 were by TF Martin ${ }^{116}$ and H Dean Bamford. ${ }^{117}$

It is more difficult to discern any other element of New Zealand writing in British law journals. The Juridical Review in Scotland published a number of articles referring to Canadian and Australian law but two referred to New Zealand law. Neither was, as far as I can tell, by a New Zealand author, although as one is a brief anonymous note (dealing with the protest of the New Zealand judges in Wallis's case) we cannot be certain. That note is sympathetic to the judges' position. ${ }^{118}$

The premier legal publication of the period - for the British Empire at least - was the Law Quarterly Review. I have only found one article directly bearing on New Zealand law in that journal, again by Sir Robert Stout. It appears primarily intended to suggest that the Privy Council

114 CE Weigall "Industrial Arbitration and Common Law Rights" (1904) 2 Commonwealth LR 248-255; GJ Meillon "The Union Label" (1905) 3 Commonwealth LR 70-75.

115 Sir Robert Stout "Appellate Tribunals for the Colonies" (1904) 2 Commonwealth LR 3-13. Stout was not the only judge to criticise the Privy Council: see HB Higgins "The Weakness of the Privy Council" (1906) 3 Commonwealth LR 258.

116 TF Martin "Real Property Law in NZ" (1904) 2 Commonwealth LR 19-21 and 49-56; and "Contracts of Indemnity" (1906) 4 Commonwealth LR 13-20.

117 H Dean Bamford" Unsoundness of Mind in relation to Torts" (1906) Commonwealth LR 3-12. Although the following pieces fall outside my self imposed time-frame of 1900-1906 we may also note that an anonymous article in 1907 reproduced with little editorial material large portions of the judgments, especially that of Stout CJ, in Union Steamship Co Ltd v Spendiff (1903) 23 NZLR 239: see "ExtraTerritorial Jurisdiction and the New Zealand Courts" (1907) 4 Commonwealth LR 101-109. Stout contributed another article in 1907 on local body statutory liability, "Local Bodies' Statutory Liabilities" (1907) 4 Commonwealth LR 145-153 and 193-201. In 1908 New Zealand contributions included a very long article by Maurice Richmond "The Indefeasibility of Registered Proprietorship" (1908) 5 Commonwealth LR 193-211; and a shorter piece by TF Martin "The Land Question in New Zealand" (1908) 5 Commonwealth LR 247-254.

118 See FR Sanderson "Industrial Arbitration in New South Wales" (1902) 14 Juridical Review 394 (incidentally discussing New Zealand legislation) and an anonymous author, "Z" "The Privy Council and the New Zealand Judges" (1903) 15 Juridical Review 294. 
had regularly misinterpreted New Zealand law - including, of course, reversing a decision to which Stout had been a party. ${ }^{119}$

\section{LAWYERS AND LAW SOCIETIES}

One of the key issues with which the district law societies, and through them the national society, were involved in during this time was the provision of library facilities in Wellington. There were two aspects to this. The first was a request by the Wellington Society that the other major Societies consider making some contribution to the costs of the Wellington District Society library because of the use of that library by practitioners from outside the capital who were arguing cases before the Court of Appeal. This request was generally favourably received, and the other main Societies, following the lead of Auckland, agreed to make a payment of one guinea per case in which counsel from their district appeared before the Court of Appeal. ${ }^{120}$

Agreement was much more difficult to reach on the second point. The judges, perhaps prompted by Edwards J, ${ }^{121}$ sought in 1902 to have a special library set aside for the use of the judges of the Court of Appeal. As that court sat only intermittently, there must have been an unspoken understanding that the books would be available to the resident judges in Wellington. The judges requested the very considerable sum of $£ 500$ for this purpose. The Wellington Society to whom the request was first made asked the Auckland, Canterbury, and Otago societies each to contribute one fifth of the title requested, with Wellington carrying the balance. This was met initially with flat refusal from Auckland and Canterbury, although both eventually conceded after significant pressure from the Chief Justice. When Auckland did agree to contribute one fifth of the cost, it placed a limitation on this - that none of it was to be used for textbooks. ${ }^{122}$ There was a renewed application

119 Sir Robert Stout "Is the Privy Council a Legislative Body?" (1905) 21 LQR 9.

120 See Minutes of ADLS Council, 24 February 1902, ADLS archives; Minutes ODLS Council, 25 April 1902, and ODLS AGM 6 February 1903, ODLS archives.

121 My reading of the correspondence, and my view that Edwards $\mathrm{J}$ may have been a driving force, is coloured by the fact that when he was appointed to sit in Auckland, he soon began to place pressure on the Auckland Society to provide him with a substantial library for his own personal use. Minutes of ADLS Council meetings, 21 June, 11 September, 9 October and 13 November 1905 and 28 February 1906, ADLS Archives. The Council resolved to make $£ 100$ available, only for Edwards to say $£ 125$ was needed for a "fair collection", but making some omissions from his desiderata to bring the total to $£ 135-2-9$, a sum that was approved. See also Dugdale, above n 99, 22. To be fair to Edwards, the Otago DLS had decided in 1902 to provide Williams $\mathrm{J}$ with a (very much more limited) library for his personal use. See Minutes ODLS Council 12 August 1902, ODLS Archives.

122 Thus Auckland initially refused to make any funds available, then grudgingly conceded $£ 50$ "it being understood that no further claim be made on this Society for upkeep of this Library", only to visit the matter a third time and agree to pay the full $£ 100$. See Minutes of ADLS Council 28 July, 29 September and 3 November 1902, ADLS Archives. Auckland sought to limit purchases to reports only, although this was acknowledged to include law digests. See Minutes of ADLS Council, 30 March 1903, ADLS Archives. Canterbury originally opposed any grant but fell into line: CDLS Annual Report 1902-03, CDLS Archives. 
for funds - 5500 was again sought - for the purchase of textbooks in 1905. ${ }^{123}$ Again Auckland baulked to agree, only acquiescing after further pressure from the Chief Justice. ${ }^{124}$ Characteristically Justice Edwards proposed a list of texts which went over the total agreed to be provided and the Wellington Society had to approach him to trim the list of intended purchases.

Other Law Society concerns included the timeliness, or lack of it, of the New Zealand Law Reports. At one point Wellington attempted to arrange for alternative publication of all reserved judgments through a local printer (this of course being in addition to the Gazette Law Reports then being published commercially in Christchurch). However the initiative failed because Edwards J refused to supply the text of his judgments unless he was paid the same rate as he received from the editor of the Gazette Law Reports. ${ }^{125}$

Two matters of professional behaviour which seem to have attracted attention throughout the country are the question of the extent to which legal practitioners might advertise their services or use their professional qualifications in advertising for clients in other capacities. Although the Societies deprecated such advertising, it was not until 1906 that clear guidelines began to emerge. ${ }^{126}$

123 Minutes of NZLS Council meetings 4 July 1905 and 12 October 1905, NZLS archives. In July the NZLS proposed a total of $£ 150$ for this purpose, but the judges pushed for the higher figure.

124 Minutes of ADLS Council 15 June 1906, ADLS archives. There is an interesting variation in the recording of the judges' reaction to the Auckland refusal in 1905, but the Canterbury records indicate Stout CJ to have written that "If the funds for this purpose were not provided by the Law Societies the Government would have to be approached, and this might involve an alteration of the present system of allowing the Law Societies to retain the admission and practicing fees paid by members of the profession". See CDLS Annual Report 1906-7, CDLS Archives. In a person of less august position, this might have been thought to smack of illegitimate pressure. There is reason to believe a similar threat was made in 1902: see the response of the ODLS Council, reproduced by Cullen, above n 102, 72. Perhaps such arm-twisting is no more alien to our views of ethical behaviour than the conflicts of interest inherent in having WS Reid, then Solicitor-General, take a leading role in the Wellington and New Zealand Law Societies.

125 It is not clear whether Edwards was attempting to supplement an inadequate judicial salary or was simply greedy. The well-known story of Edwards in his Auckland days typing copies of his notes of evidence and invoicing practitioners for them in the name of his daughter (see Cooke, above $n 4,58$ ) may equally be read in either sense. We do know Denniston J was then in severe financial difficulties, somewhat alleviated by the 1904 increase: see JG Denniston A New Zealand Judge (AH \& AW Reed, Wellington, 1939) 102.

126 The issue seems to have been ventilated by Canterbury in 1904, and referred to the New Zealand Law Society which expressed disapproval of "any advertisements of a nature soliciting business, and also any advertisement referring to a person's status as a barrister", a view subscribed, see CDLS Annual Report 15 March 1905, CDLS Archives; minutes NZLS Council Meeting 1 July 1904, NZLS Archives; Minutes ADLS Council 30 May 1904, ADLS Archives; and Minutes ODLS Council Meeting 10 June 1904, ODLS Archives. In 1906 Wellington re-visited the issue and set out much more detailed guidelines, see Minutes WDLS Council meeting 25 June 1906, WDLS Archives. These appear to have been widely accepted elsewhere, see for example Minutes ODLS Council 27 July 1906, ODLS Archives. The topic was not new - 
The second is the institutional response to a practice which had apparently developed whereby vendors of subdivided land would attempt to require through a provision in the conditions of sale that the purchaser pay the vendor's solicitor's costs of perusing the agreement for sale and purchase. All Societies disapproved of this, and Otago even attempted, without success, to have the profession agree not to insert such a clause. ${ }^{127}$

\section{OF WALLIS'S CASE AND PRIVY COUNCIL APPEALS}

It is essential to remember that only three years before Salmond's return to New Zealand there was one of the most notorious events of New Zealand's relatively brief legal history - the Protest of the Bench and Bar at the decision of the Privy Council in Wallis $v$ Solicitor-General.

The facts of that protest are well known and need not be traversed here. ${ }^{128}$ However it is material to note that the issue was one of general public interest and not merely a matter for lawyers alone - at least one newspaper published as a separate pamphlet for general sale a complete report of the Privy Council decision and of the Protest of the Bench and Bar. ${ }^{129}$ It may also be significant to note that even before there was litigation about the Porirua lands, Māori had been seeking Government intervention to ensure the promises of the church were maintained. ${ }^{130}$ After the litigation a Royal Commission was appointed to look at the question of the use of such trust lands. ${ }^{131}$

However upset many local lawyers were about the comments made in, or about Wallis's case, it did not lead to any widespread questioning of the wisdom and worth of a continued connection to the Privy Council. ${ }^{132}$ The issue of such appeals was ventilated in Parliament in 1904, and a statement by the Premier that he saw no basis for change appears to have led to a series of further public comments on the issue. ${ }^{133}$ A few days later a leading lawyer (and Government Member of

Otago had considered complaints of improper advertising against Ethel Benjamin: see Brown, above n 92 , 34.

127 See Cullen, above n 102, 69-70. See also Minutes WDLS Council 25 June 1906, WDLS archives.

128 The text of the protest is reproduced as an appendix to von Haast New Zealand Privy Council Cases 18401932, above n 77, 760-790.

129 The Evening Star Dunedin produced a 52 page pamphlet, copies in the Stout Pamphlet Collection, Victoria University of Wellington Law Library.

130 See (21 September 1900) 114 NZPD 117 (HR)

131 See Governor's Speech (27 June 1905) 132 NZPD 2 (LC). The Commissioners appointed in 1907 were Sir Robert Stout and Apirana Ngata.

132 Although Baume wanted to end appeals to the Privy Council, he had in mind that cases might instead go to the House of Lords. See (8 July 1903) 123 NZPD 253 (HR).

133 See (13 July 1904) 128 NZPD 394-95 and 401. 
the House of Representatives) JG Findlay suggested in the press that even if the Privy Council was not an ideal final appellate court, it should be retained in preference to New Zealand joining a transTasman Court (as Seddon had, perhaps mischievously, claimed had been suggested by the Privy Council's critics). ${ }^{134}$

It appears that Stout, characteristically, entered into the public debate, only to draw rejoinders from Findlay and from CB Morison, President of the Wellington Law Society. ${ }^{135}$ The next event appears to have been the publication in September 1904 of an article by Stout setting out fully his ideas for a trans-Tasman appellate court. ${ }^{136}$ The NZ Times reprinted the bulk of that article on 5 November 1904, though editorially rejecting Stout's views, not least on the (perhaps sound) basis that decisions of the Judicial Committee on matters of public controversy (as with a contentious licensing case) would gain a level of acceptance which no other tribunal could be expected to match. ${ }^{137}$

For reasons which are not clear, the debate then went into abeyance until October 1905, when the Law Societies voiced support for retaining appeals to the Privy Council, including doing so in a public deputation to the Chief Justice (as was customary, their remarks were reported in the press). ${ }^{138}$ In 1906 the New Zealand Law Society formally resolved to support the retention of appeals to the Privy Council, and to communicate this resolution to the New Zealand and British governments. ${ }^{139}$

\section{CONCLUSION}

We may place the retention of links to the Privy Council firmly within the cultural tradition of deference to perceived English standards - the cultural cringe which saw even official documents of the Law Societies refer to England as "home". It is therefore possible to view many - and I suspect

134 (19 July 1904) New Zealand Times Wellington.

135 See (28 July 1904) New Zealand Times (Stout); (2 August 1904) New Zealand Times (JG Findlay); (3 August 1904) New Zealand Times (CB Morison) Wellington.

136 "Appellate Tribunals for the Colony" (1904) 2 Commonwealth LR 3-13.

137 (5 November 1904) New Zealand Times Wellington.

138 See Memorandum of Deputation, NZLS Council Meeting Minute Book, NZLS Archives.

139 The District societies seem quickly to have decided that appeals to the Privy Council should continue: Minutes of WDLS Council 3 October 1905, WDLS Archives; Minutes of ODLS Council, 6 October 1905, ODLS Archives; Minutes of ADLS Council 9 October 1905, ADLS Archives. The final form of the NZLS resolution of 1906 shows an interesting but consistent process of amendment to remove any recognition that the New Zealand profession might contribute to the dilatory process of Privy Council appeals: see Minutes of WDLS Council 25 June 1906, WDLS Archives; Minutes of informal ODLS Council Meeting 16 June 1906, ODLS Archives; Minutes NZLS Council Meeting 6 July 1906, NZLS Archives. 
most - New Zealand lawyers of this time as firmly Anglo-centric and prepared to relinquish any claims to intellectual independence in favor of deference to the inherited English laws.

This paper began with references to the progressive and social reformist nature of New Zealand society and its Government around 1900, something which was reflected both in the legislation before Parliament and in many of the cases before the courts. Thus many of the component elements of the legal world of Salmond's time are derived from colonial conditions not found in England or ideologies not yet influential there. However we would be seriously mistaken if we considered only those elements. Many lawyers - including most of the contemporary and future leaders of the profession - were of a cast of mind that was both more socially conservative and less willing to challenge the received dominant position of English legal practice and culture. I suspect that any study of changes in the legal profession and the law of New Zealand over succeeding decades will show that it is this latter group - in which John Salmond surely belongs - which was to dominate. 
